\title{
DIAGNOSTIC DIFERENȚIAL ÎN DUREREA DE SPATE AXIALĂ LA COPIL
}

\author{
Leo Stati \\ Catedra de Chirurgie, Ortopedie şi Anesteziologie Pediatrică USMF „N. Testemițanu“, \\ Chişinău, Republica Moldova
}

\begin{abstract}
REZUMAT
Cele mai multe cazuri de durere de spate axială la copil fac parte din patologia de graniță dintre specialitățile medicale şi chirurgicale.

Durerea continuă, cu o durată mai mare de 2 săptămâni poate fi semnul unei patologii severe, impunându-se investigarea clinică, de laborator şi imagistică urgentă. Sunt prezentate diverse cauze care pot produce durere dorsală axială în perioada copilăriei: boala Scheuermann, scolioza simptomatică (secundară), spondiloliza, spondilolistezis, spondilodiscitele, sacroileitele, fracturile de coloană, tumorile coloanei vertebrale şi spondiloartropatiile reumatismale.
\end{abstract}

Cuvinte cheie: durere de spate, copil, cauze

În ultimele decenii se observă tendințe negative în dinamica parametrilor principali ai sănătăţii copiilor şi adolescenților. Cea mai accentuată creştere a morbidităţii se înregistrează la copii de vârstă şcolară. În condițiile intensificării procesului educativ pe un fundal social-igienic defavorabil şi într-o situație ecologică complicată, organismul copilului necesită o activitate fizică sporită, care lipseşte din cauza factorilor enumerați $(1,2)$.

Conform datelor Biroului Național de statistică al Republicii Moldova, în anul 2008, 727.500 de tineri au fost supuşi unui screening vizând durerea dorsală axială; 8,5\%o au fost găsiți suferinzi, procent suficient de mare pentru a fi îngrijorător.

Conform clasificărilor internaționale, sindromul algic din cadrul maladiilor cu sediul în regiunea coloanei vertebrale este inclus în grupa XIII (maladii ale aparatului locomotor şi țesutului conjunctiv). În literatura medicală contemporană sindromul algic vertebrogen fără semne de afecțiune a sistemului nervos periferic sunt considerate ca patologie a aparatului locomotor.

Experiența clinică acumulată în diagnosticul acestor afecțiuni demonstrează că medicii practicieni sunt insuficient informaţi referitor la patologia „durerii de spate“ din cauza afecțiunilor aparatului locomotor, inclusiv a coloanei vertebrale, precum şi a altor afecțiuni extra-vertebrale.
Dacă durerea de spate persistă mai mult de 2 săptămâni şi/sau este supărătoare în timpul activităților fizice, se impune evaluarea diagnostică. În afara unei anamneze corecte, examenul fizic evaluează statusul global de sănătate al copilului, asocierea unor semne generale (febră, scădere în greutate), uneori modificări neurologice şi/sau a altor organe. La fetițe, examenul ginecologic este obligatoriu (3).

În Clinica Universitară de Asistență Medicală Primară, secția Ortopedie Pediatrică şi secția Medicină de Familie a Universității „N. Testemițan“ din Chişinău, pe parcursul a doi ani (2014 şi 2015), au fost examinaţi ortopedic 1.500 de copii cu vârsta între 7-18 ani. Durerea de spate a fost depistată la 9\% din total (date nepublicate).

Explorarea paraclinică orientativă cuprinde teste pentru un eventual sindrom inflamator, evaluări imunologice şi examinări imagistice pornind de la radiografia coloanei până la explorări aprofundate (scintigrafie, tomografie computerizată, RMN) atunci când evoluția bolii o impun. Metodele radiologice fiind de bază în diagnosticul durerilor de spate şi scoliozei, bine-cunoscute şi folosite pe larg în ortopedia pediatrică nu se recomandă pentru examinarea în masă şi monitorizare în dinamică a copiilor şi adolescenţilor, din cauza nivelului înalt de risc cancerigen pentru organismul în creştere. 
Deşi diferitele metode instrumentale de examinare a pacienților ortopedici au cunoscut o mare dezvoltare, examenul clinic rămâne esențial. Examenul ortopedic se realizează în poziție ortostatică (din spate, din faţă şi profil), poziție şezândă şi în decubit dorsal (2).

Există semne clinice caracteristice asociate durerilor de spate în funcţie de etiologie. Durerea joasă de spate se poate însoți de incontinență urinară sau de tulburări neurologice la nivelul membrelor inferioare (hiposensibilitate cutanată, parestezii). Această simptomatologie impune investigații specifice urgente.

Prin examenul neurologic se depistează dereglările de sensibilitate şi motricitate (2).

Este cunoscut faptul că diverse afecțiuni displazice, degenerativ-distrofice, posttraumatice şi inflamatorii cu sediul la coloana vertebrală se manifestă prin sindrom algic în regiunea spatelui $(2,3)$.

Boala Scheuermann (4), încadrată în grupa necrozelor osoase avasculare, de cauză necunoscută, este cea mai frecventă boală care se însoțeşte de durere a coloanei vertebrale la adolescent. Simptomatologia asociază durere în dreptul vertebrelor lezate şi curbură cifotică progresivă. Localizarea obişnuită este la nivelul vertebrelor toracale medii $\left(\mathrm{T}_{7}-\mathrm{T}_{9}\right)$, dar uneori mai jos, la nivelul $\left.\mathrm{T}_{9}-\mathrm{T}_{12}\right)$. Formele lombare sunt excepționale.

Durerea este atât spontană, cât şi la mişcarea de flexie şi extensie a coloanei şi la percuţia apofizelor spinoase. Intensitatea ei este variabilă, uneori poate lipsi. Absența paralelismului între durere şi gradul cifozei face ca după vindecare cifoza să persiste cu sau fără durere asociată.

Localizarea lombară evoluează frecvent fără durere în perioada adolescenței, dar se produce fragilizarea discurilor intervertebrale şi apariţia precoce, la adultul tânăr, a spondilartrozei lombare.

Diagnosticul clinic de suspiciune a bolii Scheuermann este confirmat radiologic prin apariția de neregularități ale suprafețelor corpilor vertebrali, pensare discală, cuneiformizare anterioară a corpilor vertebrali şi apariția nodulilor Schmorl (simptom radiologic caracteristic).

Scolioza esențială $(4,5)$ este o afecțiune care se însoțeşte de durere extrem de rar. Atunci când scolioza se instalează pe un fond dureros axial posterior recent apărut, este o scolioză simptomatică, secundară. Cauza principală a durerii este de obicei o infecție de vecinătate (flegmon perinefretic) care produce contractură musculară ipsilaterală cu apariția curburii coloanei vertebrale în plan frontal, având curbura cu convexitatea în sens opus.
La fel acționează şi un proces tumoral expansiv intracanalar vertebral, care în plus se poate însoți de tulburări neurologice de compresiune medulară.

Spondiloliza $(4,6)$ este considerată în prezent ca o fractură de stres şi constă în apariția unei soluții de continuitate la nivelul istmului vertebral uni sau bilateral, la nivelul $\mathrm{L}_{4}$ sau $\mathrm{L}_{5}$. Apare de obicei la sportivii care fac frecvent mişcări de hiperextensie (gimnastică, baschet).

Lombalgia este simptomul dominant, ea apărând atât spontan, cât mai ales la mişcarea de extensie a trunchiului şi la rotaţia axială. Spondiloliza unilaterală poate fi asimptomatică, descoperită întâmplător cu ocazia unei radiografii efectuată în alt scop.

Radiografia coloanei lombare în incidență oblică evidențiază linia de osteoliză la nivelul istmului vertebral. Imaginea cea mai sigură pentru diagnostic se obține prin CT-scan.

Recuperarea se obține în 4-6 săptămâni prin repaus şi imobilizarea coloanei lombare prin folosirea unei orteze adecvate.

Spondiloliza bilaterală se poate însoți de deplasarea anterioară a blocului vertebral subiacent, instituindu-se spondilolistezisul. Riscul de compresiune medulară în acest caz face ca tratamentul să fie mai agresiv impunându-se blocarea coloanei vertebrale prin artrodeză.

Spondilodiscita (7) este infecția discului intervertebral şi a corpilor vertebrali adiacenţi cu germeni piogeni banali (vechea denumire de ,osteomielită vertebrală") sau cu bacil Koch (morbul lui Pott). În $70 \%$ dintre cazuri infecția cu germeni banali afectează regiunea lombară; preponderența infecției tuberculoase este toracală.

Simptomatologia constă în rahialgii, uneori şchiopătare, febră moderată $\left(38^{0}-39^{\circ}\right)$. Percuția apofizelor spinoase în zona afectată este dureroasă. Durerea spontană este frecvent nocturnă şi nu este calmată de repaus.

Imaginea radiologică apare târziu, ca şi în osteomielita cu alte localizări. Cariile vertebrale apar primele, apoi pensarea discului intervertebral. Aceasta dovedeşte că infecția este iniţial osoasă, apoi se transmite discului. Examenul CT evidențiază mai bine şi precoce leziunile.

Infecția tuberculoasă a coloanei este tot mai rară în prezent.

Sacroileita (8) este o infecție cu germeni nespecifici a articulaţiei sacro-iliace şi a versantelor osoase ale acestei articulații.

Durerile sunt în regiunea lombară joasă, în general simptomatologia fiind foarte asemănătoare cu cea a spondilodiscitei cu sediul $\mathrm{L}_{4}-\mathrm{L}_{5}$. 
Radiografia se pozitivează târziu prin apariția de iregularități şi carii osoase, mai ales pe versantul iliac al articulației, însoțite de pensarea spațiului articular.

Pentru diagnosticul precoce este foarte utilă scintigrafia cu $\mathrm{Tc}_{99}$.

Fracturile coloanei vertebrale sunt frecvente în cadrul accidentelor de circulație şi a căderilor de la înălțime. În prezent, sporturile extreme pot avea aceleaşi consecințe.

Fractura poate interesa corpul vertebral prin tasare, mult mai rar arcul osos neural posterior. Afectarea discului se traduce prin fisurare sau strivire.

Existența traumatismului, a durerilor dorsale, uneori a semnelor neurologice şi examenul radiologic pozitiv sunt suficiente pentru diagnostic.

Hernia de disc însoțită de sindrom sciatic este rară la copil.

Durerile de postură. În cadrul unei activităţi sportive obişnuite muşchii dorsali pot lucra cu intensități diferite, ceea ce duce la oboseală mai mare din partea unora. Aceasta produce durere şi secundar schimbarea posturii, care la rândul ei accentuează durerea.

Stenoza orificiilor spinale prin care ies nervii rahidieni poate avea cauze diferite; rezultă compresiune nervoasă radiculară cu simptomatologie neurologică.

Durerea de spate idiopatică este un diagnostic care trebuie pus cu multă atenție, după excluderea oricărei cauze posibile în urma investigațiilor complexe.

Fibromialgia, boală cronică neinflamatoare, este întâlnită la adolescent. Se traduce prin durere musculară difuză, inclusiv dorsală axială a trunchiului, oboseală, disfuncție cognitivă, tulburări de somn, anxietate, depresie. La nivel central creşte sensibilitatea la durere, fapt tradus prin:

- hiperalgezie, adică durere disproporționat de mare faţă de amploarea factorului agresor.

- alodinia se manifestă prin sensibilitate dureroasă faţă de stimuli care în mod obişnuit nu produc durere (atingerea).

Tumorile rahisului, în $80 \%$ dintre cazuri, sunt benigne: cel mai frecvent se întâlneşte granulomul eozinofil, apoi osteoblastomul, osteomul osteoid şi chistul osos anevrismal. Simptomatologia constă în rahialgii însoțite de redoare segmentară a coloanei $(5,6)$.

Granulomul eozinofil se localizează la corpul vertebral şi simptomatologia sa frustă face ca de multe ori să fie descoperit în stadiul sechelar sub forma aplatizării corpului (fosta ,vertebră plană“ a lui Calvé).
Osteoblastomul şi osteomul osteoid se localizează la nivelul arcului posterior şi atunci când durerile nu au suport vizibil radiologie, scintigrafia pune în evidență hiperfixație intensă. Ulterior apare imaginea radiologică de osteoliză, uneori cu caracter suflant.

Chistul osos anevrismal are radiologic acelaşi aspect osteolitic suflant, dar localizarea de elecție este la lama vertebrală şi apofiza transversă.

Tumori ale părților moi rahidiene cu localizare variată:

- tumori intradurale-extramedulare: meningiomul (foarte rar este malign), tumori ale tecilor nervoase şi ale rădăcinilor medulare, totdeauna benigne (schwanom, neurofibrom).

- tumori intramedulare: gliomul cu localizare obişnuit cervicală, foarte dificil de extirpat chirurgical.

Sarcomul Ewing, cea mai frecventă tumoare malignă vertebrală asociază frecvent la durere manifestări neurologice. Localizat în arcul neural posterior al vertebrei, are aspectul radiologic al unei formațiuni osteolitice, mai mult sau mai puțin ovalară. Preoperator se impune examenul RMN pentru aprecierea extensiei în părțile moi vecine.

Osteosarcomul este foarte rar localizat la vertebre şi apare la adolescent.

Tumorile metastatice sunt rarisime la copil.

Spondilartropatiile juvenile (9-12) sunt un grup de afecțiuni aparținând reumatismului cronic al copilului (debut înainte de vârsta de 16 ani) având ca trăsături comune: durerea rahidiană, toracică, fesieră şi/sau redoare matinală lombară sau dorsală, artrită (articulații mari), entezită, talalgie, degete deformate, îngroşate. Alte manifestări se asociază variabil: irită acută, uretrită nongonococică sau cervicită, diaree, prezența sau antecedente de psoriazis, balanită, entero-colopatie cronică. Diferenţele privind trăsăturile clinico-evolutive, asocierile lezionale, prezența unor factori de risc au conturat următoarele forme clinice: spondilartropatia nediferențiată, spondilita anchilozantă (pelvispondilită), artrita reactivă, artrita psoriazică şi reumatismul entero-colopatiilor cronice.

În spondilartropatia nediferențiată simptomele inaugurale frecvente sunt artralgiile, artrita membrelor (monoartrita, oligoartrita, mai rar poliartrita) şi enteziopatiile. Leziunile axiale pot surveni după ani de evoluție. Durerea axială poate fi acuzată spontan sau trebuie căutată. În ordinea frecvenței s-a raportat: durere lombară, fesieră (artrită sacroiliacă), dorsalgii, cervicalgii. 
În pelvispondilita reumatismală (spondilita anchilozantă juvenilă), afectarea axială este rară la debut (10-20\%), tabloul clinic fiind dominat de artrita periferică şi enteziopatie. Durerea axială se agravează progresiv, dar dispare după instalarea anchilozei.

Reumatismul psoriazic atestat de prezența psoriazisului şi/sau a antecedentelor familiale de psoriazis, asociază dureri lombosacrate şi/sau în şold prin sacroileită, dureri în alte articulații mari.

În reumatismul entero-colopatiilor, durerea coloanei vertebrale şi a articulaţiilor sacroiliace pot apărea la momente diferite în raport cu colita (uneori după ameliorarea acesteia).

\section{CONCLUZII}

Durerea de spate cu caracter persistent (câteva săptămâni) la copil, având o paletă etiologică largă şi înscriindu-se ca simptom unic al unei entități clinice, presupune un diagnostic diferențial laborios.

Depistarea precoce şi încadrarea corectă diagnostică a durerii de spate la copil rămâne o problemă stringentă în ortopedia contemporană. Din cauza lipsei examinărilor medicale periodice în şcoli, copiii cu dureri de spate şi diformităţi ale coloanei vertebrale sunt deseori omişi, rămân fără atenţia părinților, profesorilor şi medicilor. 